Supplement of Biogeosciences Discuss., 11, 16703-16742, 2014

http://www.biogeosciences-discuss.net/11/16703/2014/

doi:10.5194/bgd-11-16703-2014-supplement

(C) Author(s) 2014. CC Attribution 3.0 License.

(c) (1)

Supplement of

\title{
Oceanic $\mathrm{N}_{2} \mathrm{O}$ emissions in the 21st century
}

\section{J. Martinez-Rey et al.}

Correspondence to: J. Martinez-Rey (jorge.martinez-rey@lsce.ipsl.fr) 


\section{Supplementary Material}

2

Table S1: Box model boundary conditions and parameters. NEMO-PISCES model output values are taken from the historical averaged 1985 to 2005 time period and the future averaged 2080 to 2100 time period.

\begin{tabular}{llll} 
parameter & quantity & units & source \\
\hline surface $\mathrm{N}_{2} \mathrm{O}$ & 10 & $\mathrm{TgN}$ & PISCES model output \\
deep $\mathrm{N}_{2} \mathrm{O}$ & 1000 & $\mathrm{TgN}$ & PISCES model output \\
yield $\mathrm{N}_{2} \mathrm{O}$ prod. from POC (e) & 0.0025 & $\mathrm{~mol} \mathrm{~N}_{2} \mathrm{O} / \mathrm{mol} \mathrm{C}$ & Nevison et al. (2003) \\
yield sea-to-air $\mathrm{N}_{2} \mathrm{O}$ flux $(\mathrm{k})$ & 0.8 & $\mathrm{~mol} \mathrm{~N}_{2} \mathrm{O}$ air $/ \mathrm{mol} \mathrm{N}_{2} \mathrm{O}$ surface & assumption that most of the surface $\mathrm{N}_{2} \mathrm{O}$ is outgassed. \\
export POC @ $100 \mathrm{~m}$ in 2005 & 6.22 & $\mathrm{PgC} \mathrm{yr}^{-1}$ & PISCES model output \\
export POC @100m in 2100 & 5.30 & $\mathrm{PgC} \mathrm{yr}^{-1}$ & PISCES model output
\end{tabular}


5 Fig. S1: Oxygen modulating function $f\left(\mathrm{O}_{2}\right)$ in the Low- $\mathrm{O}_{2}$ production pathway term included in 6 P.OMZ from Goreau et al. (1980).

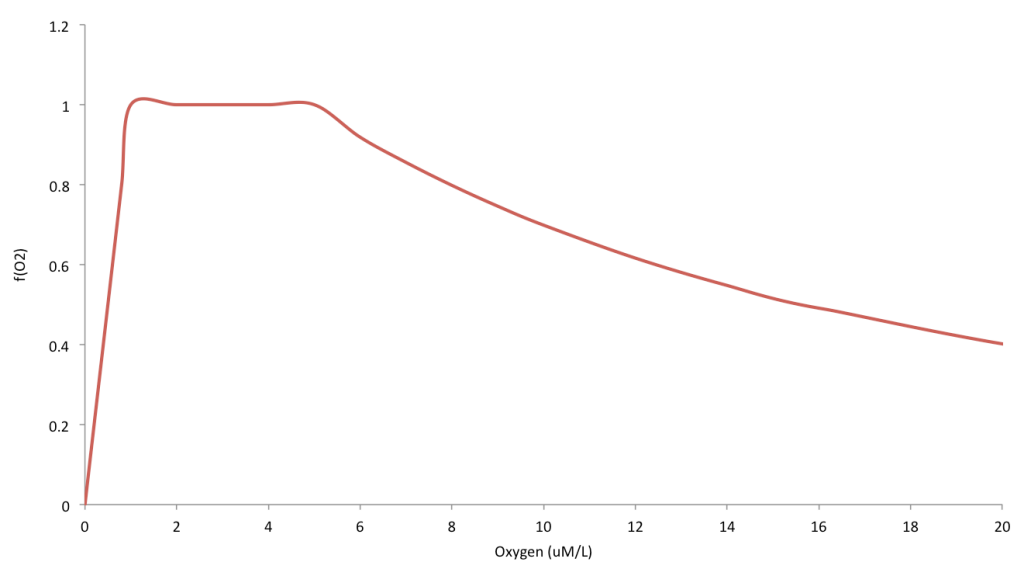


9 Fig. S2: Vertically integrated (a) high- $\mathrm{O}_{2}$ and (b) low- $\mathrm{O}_{2}$ production pathways (in $\mathrm{gN} \mathrm{m}^{-2} \mathrm{yr}^{-1}$ ) 10 in P.OMZ for the averaged 1985 to 2005 historical simulation.

11

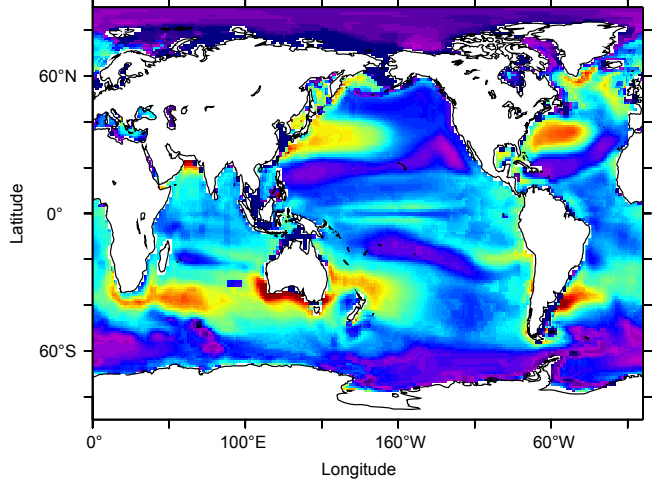

(a)

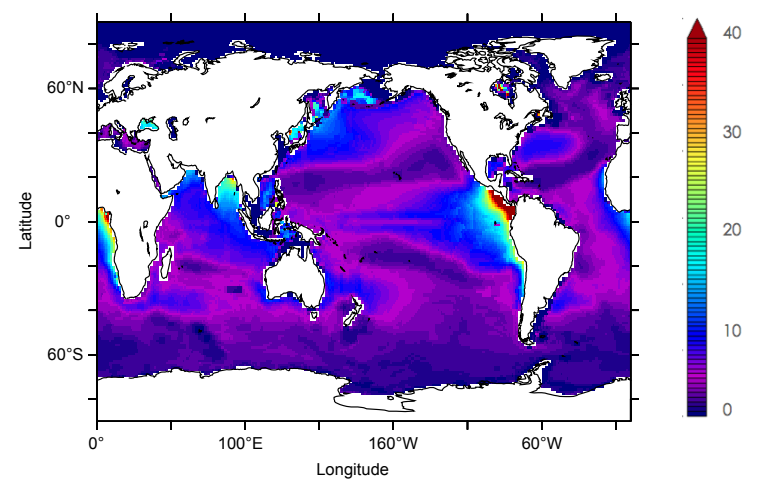

(b)

12

13 
14 Fig. S3: Diagram of the box model. $\mathrm{N}_{2} \mathrm{O}$ inventory is separated into surface and deep 15 concentrations above and below $100 \mathrm{~m}$. The fraction of $\mathrm{N}_{2} \mathrm{O}$ outgassed to the atmosphere $(k)$, 16 mixing ratio $(v)$ between deep and surface and the rate of $\mathrm{N}_{2} \mathrm{O}$ production from the export of 17 organic matter to depth (e) regulate the $\mathrm{N}_{2} \mathrm{O}$ budget in the ocean interior.

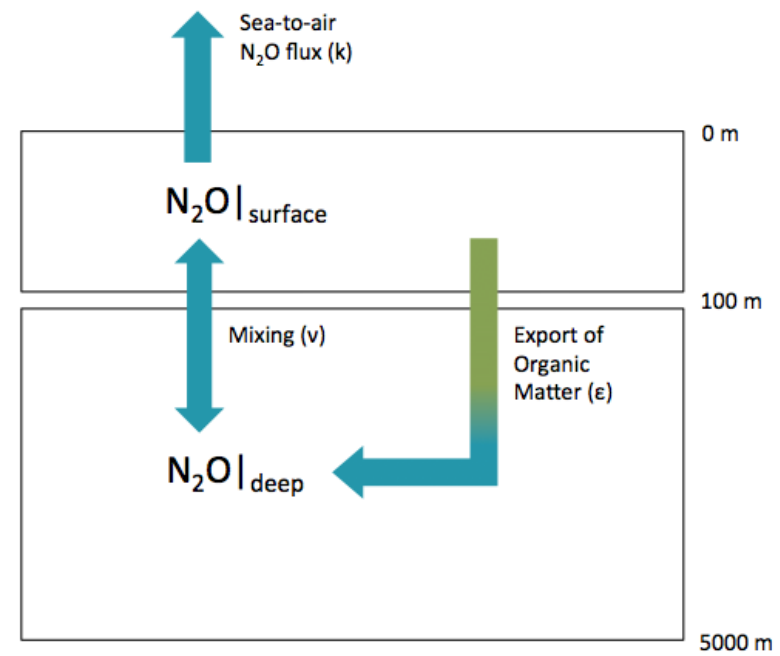

